IZA DP No. 6917

Gender, Single-Sex Schooling and Maths Achievement

Aedín Doris

Donal O'Neill

Olive Sweetman

October 2012 


\title{
Gender, Single-Sex Schooling and Maths Achievement
}

\author{
Aedín Doris \\ NUI Maynooth \\ Donal O'Neill \\ NUI Maynooth \\ and IZA \\ Olive Sweetman \\ NUI Maynooth
}

Discussion Paper No. 6917
October 2012

\author{
IZA \\ P.O. Box 7240 \\ 53072 Bonn \\ Germany \\ Phone: +49-228-3894-0 \\ Fax: +49-228-3894-180 \\ E-mail: iza@iza.org
}

Any opinions expressed here are those of the author(s) and not those of IZA. Research published in this series may include views on policy, but the institute itself takes no institutional policy positions. The IZA research network is committed to the IZA Guiding Principles of Research Integrity.

The Institute for the Study of Labor (IZA) in Bonn is a local and virtual international research center and a place of communication between science, politics and business. IZA is an independent nonprofit organization supported by Deutsche Post Foundation. The center is associated with the University of Bonn and offers a stimulating research environment through its international network, workshops and conferences, data service, project support, research visits and doctoral program. IZA engages in (i) original and internationally competitive research in all fields of labor economics, (ii) development of policy concepts, and (iii) dissemination of research results and concepts to the interested public.

IZA Discussion Papers often represent preliminary work and are circulated to encourage discussion. Citation of such a paper should account for its provisional character. A revised version may be available directly from the author. 


\section{ABSTRACT}

\section{Gender, Single-Sex Schooling and Maths Achievement ${ }^{*}$}

This paper examines the determinants of mathematical achievement among primary school children. Previous studies have found that boys perform better in maths than girls, particularly at the upper end of the distribution. It has been suggested in the literature that differences in the size of the maths gap across countries may be explained by differences in the prevalence of single-sex schooling. The Irish education system is interesting both for the fact that a sizeable proportion of children attend single-sex schools, and because these single-sex schools are part of the general educational system, rather than serving a particular socioeconomic group. We exploit this fact to test whether the gender composition of schools affects the maths differential at the top of the distribution. In keeping with research on other countries, we find a significant maths gap in favour of boys, but contrary to suggestions in the literature, our results provide no evidence that single-sex schooling reduces the gap. If anything, the gender differential is larger for children educated in single-sex schools than in co-educational schools. These findings are not affected by the inclusion of a proxy for early childhood ability or by the use of instrumental variables to control for potentially endogenous school choice.

JEL Classification: J24, 121

Keywords: gender maths gap, single-sex schooling

Corresponding author:

Donal O'Neill

Rhetoric House

NUI Maynooth

Maynooth, Co. Kildare

Ireland

E-mail: donal.oneill@nuim.ie

\footnotetext{
* We would like to thank Selina McCoy and seminar participants at the NUIM Economics Workshop, the Growing Up In Ireland Annual Research Conference, Dublin (December 2011), the Irish Economic Association Annual Conference, Dublin (April, 2012) and the 2nd RHUL - UCD Joint Workshop, UCD Geary Institute, Dublin (May, 2012) for helpful comments and suggestions on an earlier version of this paper.
} 


\section{Introduction}

The importance of mathematical skills has been well-documented. Schrøter Joensen and Skyt Nielsen (2010) provide evidence that maths skills have a causal effect on labour market outcomes and there is evidence that the individual returns to maths skills are higher than the returns to other skills (Paglin and Rufolo 1990; Grogger and Eide 1995; Buonanno and Pozzoli 2009, Koedel and Tyhurst 2012). The OECD (2010a) has emphasized the importance of mathematical proficiency for economic growth and there is concern in several countries that educational policy is not supporting children in attaining high levels of mathematical achievement. For these reasons, improving maths performance has been a key focus of educational policy for many governments. ${ }^{1}$ Although recent trends suggest that general female educational attainment has surpassed male attainment in many industrialised countries (Pekkarinen 2012), empirical evidence also indicates that boys continue to outperform girls in maths in most countries (Hedges and Nowell 1995; Close and Shiel 2009; OECD 2010b; Husain and Milimet 2009; Fryer and Levitt 2010; Bedard and Cho 2010). ${ }^{2}$ Of the 65 countries participating in the 2009 Program for International Student Assessment (PISA), boys scored better in maths than girls in 54 countries. As a result strategies to raise the performance of girls have received particular attention in both educational policy discussions and in the media. ${ }^{3}$

In recent years, single-sex schooling has received increased attention. This is partly because schools in several countries have been experimenting with single-sex classes within mixed schools in an attempt to raise overall achievement. Title IX of the US Education Act was amended in 2006 to allow more flexibility to school districts to provide single-sex education, while in the UK, a 2007 government backed review argued that boys should be taught separately, with more emphasis on 'competitive' lessons and the reading of non-fiction books (Department of Education and Skills 2007). In addition, Fryer and Levitt (2010) have

\footnotetext{
${ }^{1}$ Examples include projects aimed at addressing underachievement in maths by changing the attitudes and practices of schools, parents and children such as the Ocean Mathematics Project in London (Bernie and Lall 2008); policies aimed at increasing the amount of time devoted to maths during school time, such as the 'numeracy hour' in the UK (Machin and McNally 2005); the introduction in 2012 of bonus points for higher level maths when determining admission to university in Ireland; and the development of new assessment strategies for maths in the US (Stecher and Klein 1996).

${ }^{2}$ Meta analyses conducted by Else-Queste et al. (2010) and Lindberg et al. (2010) find negligible gender effects in average maths scores but note considerable heterogeneity across countries.

${ }^{3}$ For example in June 2012 the European Commission launched a campaign challenging stereotypes on science and encouraging young people, especially girls, to study science. In another example, pop star Will.i.am recently funded a prime time TV special called "i.am.first: Science is Rock and Roll" designed to get students, and young girls in particular, excited about learning STEM skills (science, technology, engineering and math).
} 
suggested that single-sex schooling might reduce the gender maths gap. However, the effect of single-sex schooling on outcomes is usually difficult to test (see Halpern et al. 2011), as in most countries single-sex schools are selective and the numbers attending them are small. Ireland is unusual in that a sizable proportion of primary school children (about a quarter) are educated in single-sex, non-selective, state-funded schools. For this reason, the Irish educational system provides a valuable setting for examining the effects of single-sex schooling.

In this paper, we use data on Irish children to examine the determinants of the gender maths gap at the age of nine, focussing on the impact of single-sex schooling. Concentrating on the early years of education is important because there is evidence that these are the years when the maths gap first opens up (LoGerfo et al. 2006, Fryer and Levitt 2010, Robinson and Lubienski 2011). Our results show that a gender gap in maths scores exists among Irish primary school children, particularly at the upper end of the distribution, but there is no evidence that single-sex schooling reduces the gap. In fact our results suggest that the gender maths gap may be larger for children attending single-sex schools.

The remainder of the paper is structured as follows. Section 2 provides a review of the literature. Section 3 describes the Irish educational system and Section 4 describes the data we use. Section 5 reports our results and Section 6 concludes.

\section{Literature Review}

A number of recent studies have analysed the gender gap in mathematical performance among children. Halpern et al. (2007) provide a comprehensive summary of the literature, looking at both the biological and sociocultural forces that may contribute to sex differences in maths. They conclude that the observed male advantage in mathematics is largest at the upper end of the ability distribution and that many variables work together in a complex way to determine this gender gap.

Fryer and Levitt (2010) use the Early Childhood Longitudinal Study Kindergarten Cohort (ECLS-K) and find that girls and boys in the US were observationally equivalent in both maths and reading when they entered kindergarten (normally at age 5 or 6 ), but by the end of fifth grade (when the children were usually aged 10 or 11), girls had fallen more than 0.2 standard deviations behind their male counterparts. Explanations for this gender gap fall 
into two broad categories: biological theories such as differences in innate spatial ability or greater male variability in intellectual abilities, and societal factors such as differences in expectations of girls and boys. Fryer and Levitt test some of the societal theories by controlling for such variables as differential ratings by teachers, parental expectations, whether a child's mother worked in a maths-related occupation and the amount of time parents spent doing maths-related activities with children. They find that none of these have a substantial effect on the gender gap.

To gain further insight, Fryer and Levitt use two international datasets, the Trends in International Mathematics and Science Study (TIMSS) and PISA to investigate whether the size of the maths gap is related to gender inequality. As a measure of the latter, they use the World Economic Forum (WEF) gender gap index, which reflects economic and political opportunities, education and well-being for women. The authors find a strong positive relationship between gender equality and the relative performance of girls in maths using PISA $^{4}$ but not when using TIMSS. The difference in results is driven by the fact that TIMSS includes a large number of Middle Eastern countries that are not in PISA. Although these countries have a high degree of gender inequality, there is no gender gap in maths. The authors tentatively suggest that this may be due to the prevalence of single-sex schools in these countries.

There is substantial debate on the impact of single-sex schooling on academic performance. Riordan (1985) found a significant advantage to single-sex education for girls but not for boys. Likewise Bryk et al. (1993) found positive effects for girls' academic achievement as well as for social and personal development outcomes in girls' schools. However, Billger (2009) argues that much of the effect of single-sex schooling among private schools in the U.S. accrues to students already likely to succeed and concludes that overall her results “do not provide a ringing endorsement of single-sex education.” Halpern et al. (2011) go further and argue that there currently exists no well-designed research showing that single-sex education improves students' academic performance, but that there is evidence showing that sex segregation may increase gender stereotyping and, by doing so, legitimise sexism. They quote Smithers and Robinson (2006) who conclude that "[ $t$ ]he paradox of single-sex and co-education is that the beliefs are so strong and the evidence so weak.”

\footnotetext{
${ }^{4}$ See also Guiso et al. (2008).
} 
Mael et al. (2004), Robertson Hayes et al. (2011) and Sullivan et al. (2010) all discuss potential mechanisms by which sex-segregated schools might affect the academic performance of girls. Some proponents of single-sex schooling argue that it is beneficial for girls because teachers' and peers' sexist attitudes interfere with girls' learning in coeducational schools. Smyth (2010), Sullivan et al. (2010) and Schneeweis and Zweimuller (2012) note that educational choices may become more gender-stereotyped in a coeducational setting, although Sullivan et al. (2011) note that this does not explain the singlesex wage premium for girls in later life. Recent work by McCoy et al. (2012) reports that girls in single-sex primary schools in Ireland are more likely to have a positive attitude towards maths than girls educated in a co-educational setting. While in general boys are more positively disposed towards maths than girls, the authors find that there is little difference in attitudes to maths between boys and girls educated in single-sex schools. Proponents of single-sex education also note that boys tend to seek out and receive the majority of teacher attention in co-educational classes, particularly in subjects like maths and science (Bracey 2006). There is also a belief that boys and girls learn differently and educational instruction is more effective when it is tailored to these differences.

Another explanation as to why single-sex schooling may affect the achievement gap focuses on gender differences in response to competition. A number of papers investigate these differences using an experimental approach. For example, Huguet and Regner (2007) find that when girls are led to believe that a task measures maths ability, they underperform in mixed-sex groups but not in all-female groups. Gneezy et al. (2003) test reactions to competition in maths puzzles by boys and girls and conclude that it is not that women are unwilling or unable to perform well in competitions per se, but rather that they do not compete well in competitions against men. Gunther et al. (2010) replicate the experiment used in Gneezy et al. (2003) and extend it to include 'gender-neutral' and 'female' tasks as well as the maths competition, which they regard as a 'male' task. For the male task, they replicate the original results. However, for the gender-neutral task, women react as strongly as men and for the female task, women react more strongly than men. They conclude that both men and women tend not to compete in areas where they perceive that their gender is disadvantaged. Cotton et al. (2010), using data from multiple-period competitions, confirm that there can be a male advantage, but suggest this declines after the first period. They also find that the initial advantage only arises if the competition is structured as a race and involves maths; it does not hold for reading questions. 
Gneezy et al. (2009) use a controlled experiment to look at gender differences in competition across two distinct societies: the Masai in Tanzania, which is considered a patriarchal society and the Khasi in India, which is matrilineal. They find that Masai men are more likely to compete than Masai women, while Khasi women are more likely to compete than Khasi men. However, they caution about generalizing these results to other societies.

Booth and Nolen (2012) study a sample of English 15 year old students from coeducational and single-sex schools to examine the role of nurture in explaining why women may shy away from competition. They find that girls who are randomly assigned to all-girl groups are significantly more likely to be competitive. They also compare the behaviour of girls and boys attending single-sex and co-educational schools. They find that girls attending single-sex schools behave more competitively than girls in co-educational schools. For boys, they find that neither attendance at single-sex schools nor the gender make-up of boys' experimental peer group have any explanatory power in whether they choose to compete.

Hoxby (2000) and Lavy and Schlosser (2011) report evidence that the achievement of both boys and girls is increasing in the fraction of females in their peer group. Students who have more female peers report a lower level of classroom violence and better relationships with other students and teachers. In addition, their evidence suggests that teacher fatigue and burnout are inversely related to the proportion of girls in a class, in which case, single-sex schooling will increase the performance of girls, but at the cost of poorer achievement by boys.

Eisenkopf et al. (2012) analyse the impact of female-only classes on mathematical achievement, exploiting random assignment of girls into single-sex and co-educational classes in a Swiss secondary school. They find that single-sex classes improve the performance of female students in maths and that this positive effect increases if the singlesex class is taught by a male teacher. However, the paper does not examine the impact of single-sex education on the gender maths gap; moreover, it focuses on girls in a single school that caters for students who intend to become teachers, making the results hard to generalize.

The evidence on the direction of the teacher gender effect is mixed. Dee (2007) finds that both boys and girls are adversely affected when taught by a female maths teacher. If the gender composition of teaching staff at a school reflects the gender composition of the students, this result would lead to single-sex education increasing rather than reducing the gender effect. In contrast, Carrell et al. (2010) find that girls, particularly those at the top of 
the distribution, perform better in maths and science when taught by a female professor, whereas professor gender has no effect on boys’ performance.

Finally, Park et al. (2011) examine the impact of gender composition of schools on STEM careers in Korea and find a significant causal effect of all-boys but not all-girls schools. This paper differs from ours in that they look at the impact of single-sex high-school education on academic performance at tertiary level, whereas we focus on earlier academic outcomes. In fact, almost all of the previous studies of single-sex schooling have focused on single-sex education at either secondary school or university level. Of the studies evaluated by Mael et al. (2005), only the work by Lee and Lockheed (1990) considers the impact on maths of single-sex education at primary level. They find that single sex education positively affects maths achievement for girls and negatively affects it for boys in a sample of Nigerian primary school children. However, the authors note that the analysis is complicated by the fact that significantly fewer girls attend school in developing countries ${ }^{5}$ and prevailing social attitudes favour the intellectual advancement of boys.

\section{Description of Irish Primary School System}

Primary schooling in Ireland begins when children are aged four or five and lasts for eight years. The vast majority of primary schools in Ireland are state-aided parish schools, having been established under church patronage with the state giving explicit recognition to their denominational character. $92 \%$ of primary school children are educated at Catholic denominational schools, with the remainder attending non-Catholic denominational schools and multi-denominational schools.

Of the Catholic schools, a sizeable minority are single-sex schools simply because they were established at a time when separate schooling for boys and girls was the norm. These single-sex schools continue to exist mainly in older residential areas in cities and towns where the school-going population is large enough to sustain (at least) two separate schools. Department of Education figures for 2007 indicate that $27 \%$ of girls and $25 \%$ of boys of primary-school age were educated in single-sex schools in Ireland. This is unusually high by

\footnotetext{
${ }^{5}$ Lee and Lockheed (1990) report that less than 15\% of the female cohort aged 12-17 was enrolled in secondary school.
} 
international standards. For example, in the UK just two single-sex state primary schools exist, accounting for fewer than 600 pupils. $^{6}$

The Department of Education and Skills in Ireland classifies schools according to their socio-economic mix using a standardised system. The DEIS (Delivering Equality of Opportunity in Schools) classification system is based on a range of factors such as parental unemployment, family type and size, and family income. Primary schools serving rural communities including towns with a population below 1500 can receive DEIS Rural status, while other schools may be designated as DEIS Urban 1 or DEIS Urban 2. Schools with a designated DEIS status receive extra resources; those given DEIS Urban 1 status are deemed to be the most disadvantaged and so receive the greatest level of additional support. Approximately 20\% of primary schools in Ireland are designated as DEIS schools.

Irish parents can choose which schools they want their children to attend. Schools are not obliged to admit all children who apply but most schools operate a 'catchment area', whereby they commit to accepting all children of school-going age living within a particular area. There are very few fee-paying schools at primary level in Ireland; less than $3 \%$ of students attend fee-paying primary schools.

Ireland is therefore unusual both for the fact that a sizeable proportion of children attend single-sex schools, and because these single-sex schools are part of the general educational system, rather than serving a particular socio-economic group.

\section{Data}

The Growing up in Ireland (GUI) survey tracks the development of a cohort of children born between November 1997 and October 1998. The data used for our analysis are from the first wave of interviews, which were carried out between August 2007 and May 2008. ${ }^{7}$ The survey sample was generated through the national primary school system. 910 randomly selected schools participated in the study. Information was collected from the children, their parents, their teachers, the school principals, and their childminders (where relevant). As part of the survey, each child sat reading and maths tests, which were administered by GUI

\footnotetext{
${ }^{6}$ Source: Ofsted Inspection Reports for Winterbourne Junior Boys' school and Winterbourne Junior Girls' school.

${ }^{7}$ Only the first wave is available to date.
} 
fieldworkers at the child's school. These tests, known nationally as 'Drumcondra' tests, have been used for many years in Irish schools and are linked to the national curriculum. The Drumcondra test results, in the form of logit scores, provide the outcome variables of interest for this analysis.

The parents provide information on variables such as household composition, income, occupation, parental education, and the child's health, lifestyle and education. The children themselves also answer questions about home, school, diet and activities. The child's teacher was asked to complete two short questionnaires, the first about the school and the second about the child's performance in school. The child's school principal was also asked to complete a short questionnaire about the school. Some administrative data were also provided with the Research Micro-File, including information on whether the school is co-educational or single-sex.

In our analysis, the sample includes all children apart from those in 'special schools', which provide education to children whose needs cannot be accommodated in mainstream schools. These account for less than $0.5 \%$ of children in the sample. This gives a base sample of 3943 girls and 3700 boys. In later sections we include a range of additional control variables, some of which are missing for some of the sample. The inclusion of these additional controls reduces the number of girls and boys to 3578 and 3345 respectively.

The administrative data provided with the survey allow us to distinguish among three school types - boys-only, girls-only and coeducational. $11 \%$ of schools in the sample are boys-only, $12 \%$ are girls-only and $77 \%$ are coeducational. Since single-sex schools are more likely to be located in urban areas and so are larger on average than coeducational schools, the percentages of children attending single-sex schools are higher, with $14 \%$ of the sample in girls-only schools and $15 \%$ in boys-only schools. Table A1 provides additional summary statistics for all the variables used in the paper.

\section{Results}

\section{a. Establishing the Gender Maths Gap}

Table 1 summarizes the distribution of reading and maths scores for the boys and girls in the sample, while Figure 1 provides Kernel density estimates of these distributions. We first 
compare the distributions of reading scores. A Kolmogorov-Smirnov test rejects the hypothesis that the two distributions are equal, with a p-value of 0.027 . While there is no significant difference in mean reading scores between boys and girls, and no difference among high achievers, Figure 1 shows that girls perform better than boys at the lower end of the distribution.

Examining the maths distributions, the p-value for the Kolmogorov-Smirnov test of equality of the maths distributions across genders is equal to 0.000 , again rejecting equality of the maths distributions. However in contrast to the reading scores, we now see that boys do better than girls: there is a significant difference in mean mathematics scores and this difference is driven by the fact that boys are outperforming girls at the top of the distribution rather than at the bottom. This finding of a significant gap at the top end of the maths distribution is consistent with the literature reviewed by Halpern et al. (2007), as well as recent work by Ellison and Swanson (2010) who examine at the gender gap for very high achievers in maths in the US.

The vertical lines in Figure 1 show the cut-off points for the top quartile of the score distributions in our sample. Since this is the point where the difference in maths scores between boys and girls becomes most pronounced, we focus on the top quartile in our analysis.

\section{b. The Impact of Single-Sex Schooling on the Gender Maths Gap}

Examination of the data shows that $29 \%$ of males are in the top quartile of the maths distribution, compared to $22 \%$ of females. To analyse this difference in more detail, we estimate probit models where the dependent variable, $\mathrm{Q}_{.75}$, is equal to one if the individual has a maths score in the top quartile and zero otherwise. Specifically,

$$
\operatorname{Pr}\left(Q_{.75}=1\right)=\Phi(\alpha \text { Male }+\beta \text { SingleSex }+\gamma \mathrm{X})
$$

where $\Phi$ is the standard normal cdf, Male is a dummy variable taking the value one for male, SingleSex indicates the gender composition of the child's school and $\mathrm{X}$ is a vector of additional control variables. 
The key findings for this section are presented in Table 2. Controlling only for gender, results in the first column confirm that the gender gap is statistically significant; the marginal effect indicates that being male increases the probability of being in the top quartile by 7 percentage points.

We now examine the extent to which single-sex schooling affects this gender gap. We begin by plotting the distributions of maths scores by gender and school type. Thus the distributions in Figure 2 are for boys attending coeducational schools, boys attending boysonly schools, girls attending coeducational schools and girls attending girls-only schools. The first point to note is that the differences occur primarily amongst those with high maths scores. Secondly, the ordering of the distributions indicates that boys perform better than girls, irrespective of school type, although the gap is most pronounced for boys attending single-sex schools. Finally, there appears to be little difference in the performance of girls at coeducational and single-sex schools.

To examine the impact of single-sex education on the gender gap in more detail, in column (2) of Table 2, we extend the model to control additionally for the type of school attended. The male coefficient now measures the gender maths gap in coeducational schools; this coefficient remains positive and significant. If single-sex schooling reduces the maths gap (as speculated by Fryer and Levitt 2010), we expect girls to perform better in single-sex schools than in coeducational schools, and the girls' single-sex premium to be bigger than any boys' single-sex premium. In fact, the effect of attending an all-boys school is positive and marginally statistically significant, whereas the effect of attending an all-girls school is insignificant. Thus, there is no evidence to support the hypothesis that single sex schooling reduces the gender gap in maths achievement; if anything, it exacerbates it. $^{8}$

Since parents have some choice as to which school their child attends, which may be related to school characteristics such as gender composition and the socio-economic mix of the school, it is important to control for these factors in estimating the effect of single-sex schooling. The final column of Table 2 controls for parental education, which is an indicator variable for whether either of the parents has a degree; family income, which is total household income measured in thousands of euro; father absent, which is a dummy variable

\footnotetext{
${ }^{8}$ These results are consistent with findings of Park et al. (2011).
} 
taking the value one if the child's father does not live with the child ${ }^{9}$; and the socio-economic mix of the school, which is measured by its DEIS status, as discussed earlier. ${ }^{10}$

Looking at these additional variables, we find that they are all significant in determining whether a child's score is in the top quartile of the maths distribution. The coefficient on parental education indicates that the children of graduates are 12 percentage points more likely to score in the top quartile; an additional $€ 10,000$ of income is associated with a 1 percentage point increase in the probability of being in the top quartile; and children who live in a house where the father is not present are 6 percentage points less likely to score in the top quartile. Not surprisingly, students in schools with DEIS status are significantly less likely to score in the top of the maths distribution.

For the purposes of our research question, it is important to note that the inclusion of these additional variables does not affect our earlier conclusions. Boys in single-sex schools are 4.4 percentage points more likely to score in the top quartile than boys in co-educational schools, an effect that is significant at the $5 \%$ level. There is no corresponding effect of girls' single-sex education. As a result, single-sex schooling increases the gender gap; the male dummy indicates that boys in co-educational schools are 5 percentage points more likely than girls to be in the top quartile in maths, whereas the gap is 8.5 percentage points for children in single-sex schools.

Although not the focus of this paper, it is worth noting that the impact of single-sex schools on reading scores is similar to the effect on maths scores. Boys attending single-sex schools are more likely to score in the top quartile than boys in co-educational schools. As before, there is no significant effect of single-sex education for girls. In contrast to the results for maths however, there is no gender gap in reading scores for students educated in coeducational schools. These results are reported in Table A2 of the Appendix.

In the above analysis we have shown the existence of a significant gender gap in mathematical achievement at the top of the test distribution. We find no evidence that singlesex schools reduce this gap; if anything the gender gap is wider among students attending single-sex schools than among those in co-educational schools. Given the nature of the Irish

\footnotetext{
${ }^{9}$ This includes cases where the child's father is deceased or living temporarily away from home.

${ }^{10}$ In the results reported here we only distinguish between DEIS and non-DEIS schools. We also carried out the analysis using the finer DEIS classification. This made almost no difference to our final results, but we chose not to present these results as some of the cell-sizes become very small when the other controls are combined with the finer DEIS classification.
} 
educational system we believe that our results on single-sex schools are less likely to be affected by self-selection bias than would be the case in other countries. In the final part of this section we examine the robustness of our findings to this exogeneity assumption.

The main concern in this literature is that populations attending single-sex schools may differ in unobservable ways from those attending co-educational schools. In this case, the earlier estimates cannot be interpreted as causal effects. In addition, if the decision to send children to single-sex schools differs for boys and girls then the gender comparison is compromised. A number of approaches have been suggested for dealing with endogenous selection into single-sex schools. Here we consider two approaches adopted in a recent paper by Booth and Nolen (2012). The first approach uses a measure of the child's cognitive ability as an additional control variable in the analysis. Ideally, we would like to have pre-school test scores for each child but these are not available in our data. Instead we use information on the child's birthweight. There is a growing literature on the causal effect of birthweight on later outcomes (Currie and Hyson 1999; Black et al. 2011) and much of this research finds evidence linking low birthweight to poor health, cognitive deficits and behavioural problems among young children. Birthweight has also been used directly as an input when estimating the production function of cognitive achievement for young children (Todd and Wolpin 2007). Including birthweight as an additional control is in keeping with the 'value added' approach to addressing endogeneity (Todd and Wolpin 2003). The second approach uses geographical data to construct plausible instruments for school choice. In our data $43 \%$ of students living in an urban area attend a single-sex school compared to only $18 \%$ of students living in rural areas. Since students in urban areas are much more likely to attend single-sex schools, we use an urban indicator as an instrument for school choice. Our identifying assumption is that, conditional on a range of family characteristics and the socio-economic mix of the school, the rural-urban indicator should not directly affect the mathematical performance of the child.

The results from these sensitivity checks are given in Tables 3 and 4 . Table 3 shows the results for the approach that uses birthweight as a proxy for pre-school ability. Because birthweight is not available for every child, the first column presents results for the same specification as in column (3) of Table 2, but for the slightly reduced sample. The second column reports the results when birthweight is added as a control variable. In keeping with previous research, we find that low birthweight has a significant negative effect on the maths achievement of children at age nine. A one kilogram increase in birthweight increases the 
likelihood of scoring in the top quartile of the maths distribution by 2.4 percentage points. While this result is of interest in itself, what is important for our analysis is that neither the gender maths gap nor the single-sex school effects are changed by the inclusion of this measure of pre-school ability.

Table 4 shows the results from a bivariate probit model of maths performance and choice of school type, with an urban indicator used to instrument for school choice. Given the bivariate specification of the model, we have estimated the model separately for boys and girls. The first and third columns show the results for the school choice decision for boys and girls respectively, while the second and fourth columns give the results for maths performance. The impact of geography on school choice is as expected, with boys and girls living in urban areas significantly more likely to attend a single-sex school. The other estimates in the model for school choice support our view about the absence of selection into single-sex schools. For boys, none of the parental background characteristics are significant determinants of school choice, while for girls only the absence of a father seems to matter; girls in families where the father is not present are more likely to attend a single-sex school. The insignificance of parental income and parental education in both specifications is in keeping with the public nature of single-sex schools in Ireland and confirms our belief that single-sex schools in Ireland are not elitist. Furthermore if selection on unobservables were explaining the impact of single-sex schools on maths outcomes, we would expect the estimated value of $\rho$ from the bivariate probit to be positive. However, the results in Table 4 show that $\rho$ is negative for both boys and girls, although it is only significant at the $10 \%$ level for boys and statistically insignificant for girls.

The results for the determinants of the maths score accounting for potential endogeneity are shown in columns (2) and (4) and confirm our key findings. Boys in singlesex schools perform better than boys in co-educational schools, while there is no evidence that school type affects the performance of girls. Consequently, the gender gap is larger for children attending single-sex schools than for those attending co-educational schools.

\section{c. Examining Other Explanations of the Gender Maths Gap}

In the final section of the paper we consider alternative explanations of the gender maths gap. Firstly, as noted earlier, there is evidence that teacher gender may affect students' outcomes. 
Since in our data, boys are more likely to be taught by male teachers (18\% of boys have a male teacher compared to only $11 \%$ of girls), then any teacher gender effect could in part explain the gender maths gap. To examine this we include an additional control for the gender of the child's teacher. Secondly, we include a control for whether the mother's occupation is maths related. ${ }^{11}$ This is intended to capture the possibility that the presence of a female role model in the family might counteract gender stereotyping, and so prevent maths being viewed as a male subject. Thirdly, we include a control variable measuring whether or not the main care giver (almost always the mother) deems the division of housework between parents to be unfair. Fryer and Levitt (2010) and Guiso et al. (2008) argue that the gender maths gap is smaller in countries with a more gender-equal culture and the inclusion of this variable is intended to allow for the possibility of a similar effect between families. Finally we also include a control variable for being in a mixed gender household. Just as girls' attitudes to maths may be affected by the presence of boys in coeducational schools, this may also be true if they grow up with brothers. Since the likelihood of growing up in a mixed gender household is higher in households with larger families, we also control for family size to assist with interpretation of the results.

The results of this extended analysis are given in Table 5. Because the inclusion of the additional control variables leads to a slightly smaller sample, we have also re-estimated our base model on this reduced sample; the estimates for this base model are given in the first column of Table 5 and are very similar to our earlier results. The results for the extended model are given in the second column of Table 5. Looking at the coefficients on the new control variables we find no evidence that the gender of the teacher, the division of housework within the family or the gender mix of the household have any effect on maths performance. The insignificance of the effect of teacher gender on maths performance is consistent with the results of McCoy et al. (2012) who find that the gender of a child's teacher has no effect on the attitudes of boys and girls to maths in Irish primary schools.

\footnotetext{
${ }^{11}$ Maths-related occupations are based on the 4 digit ISCO classification of occupations and are defined to include meteorologists, chemists, geologists and geophysicists, mathematicians and related professionals, statisticians, computer systems designers, analysts and programmers civil engineers, electrical engineers, electronics and telecommunications engineers, mechanical engineers, chemical engineers, accountants, economists, chemical and physical science technicians, civil engineering technicians, electrical engineering technicians, electronics and telecommunications engineering technicians, securities and finance dealers and brokers bookkeepers, statistical, mathematical and related associate professionals accounting and book-keeping clerks, statistical and finance clerks and mechanical engineering technicians. Where the mother is not currently working her most recent occupation is used.
} 
We find that having a mother with a maths-related occupation has a significant positive effect on maths scores. This may be a causal effect, reflecting inherited innate ability or a more positive disposition to the subject. On the other hand, the variable may be picking up some measure of social class not captured by income or education. However, it is interesting that results from a separate analysis not included here indicate that the mother's maths occupation is insignificant when included as a control in a model of reading scores. This is not what we would expect if the mother's maths occupation was simply proxying for social class.

While these individual coefficients are of interest in their own right, our key finding is that the inclusion of these additional controls does not explain the gender maths gap. The male advantage in maths remains large and significant even when these additional family and teacher controls are included.

\section{Conclusion}

In this paper, we examine the gender gap in maths scores using a representative sample of nine year old Irish school children. We find that boys perform better than girls, with the difference most pronounced at the top of the distribution. We exploit the fact that single-sex schooling is widespread in Ireland to test whether the gender composition of schools affects the gender maths gap at the upper end of the ability distribution. Although previous research has found that girls educated in single-sex schools in Ireland are more likely to have a positive attitude towards maths than those educated in co-educational schools, we find no evidence that this effect manifests itself in better performance in the subject. Boys attending single-sex schools do better than boys in co-educational schools, whereas there is no corresponding difference for girls; consequently, the gap is larger for children educated in single-sex schools. The interpretation of these results is predicated on the assumption of exogenous school choice, conditional on key family background variables. While parents do have some control over which schools their children attend, our analysis suggests that selection is not a factor in our results. Our analysis also shows that the gender gap in maths remains even after controlling for an additional set of family and teacher characteristics. This suggests that policies based on some common explanations of the maths gap are unlikely to reduce it. 
Our results are in keeping with the findings of Fryer and Levitt (2010), who also failed to find support for a number of potentially important prior explanations in their analysis. One alternative hypothesis tentatively suggested by these authors is that "mixedgender classrooms are a necessary component for gender inequality to translate into poor female math performance”. The unusual characteristics of the Irish education system provide us with an opportunity to test this hypothesis, and we find no evidence that the maths gap is bigger in mixed gender schools. 


\section{References}

Bedard, K. and I. Cho (2010), "Early Gender Test Score Gaps Across OECD Countries," Economics of Education Review, vol. 29, pp. 348-363.

Bernie, J. and M. Lall (2008), "Building Bridges between Home and School Mathematics: A Review of the Ocean Mathematics Project,” Institute of Education, University of London.

Billger, S. (2009), "On Reconstructing School Segregation: The Efficacy and Equity of Single-Sex Schooling,” Economics of Education Review, vol. 28, pp. 393-402.

Black, S., P.J. Devereux and K.G. Salvanes (2007), "From the Cradle to the Labor Market? The Effect of Birth Weight on Adult Outcomes," The Quarterly Journal of Economics, vol. 122(1), pp. 409-439.

Booth, A. and P. Nolen (2012), "Choosing to Compete: How different are Boys and Girls?" Journal of Behavior \& Organization, vol. 81(2), pp.542-555.

Bracey, G. (2006), “Separate But Superior? A Review of Issues and Data Bearing on SingleSex Education,” Tempe: Educational Policy Research Unit.

Bryk, A., V. Lee, and P. Holland (1993), Catholic Schools and the Common Good. Cambridge, MA: Harvard University Press.

Buonanno, P. and Pozzoli, D. (2009), "Early Labour Market Returns to College Subjects" LABOUR, Review of Labour Economics and Industrial Organisation, vol. 23(4), pp. 559588.

Campbell, P. and J. Sanders (2002), "Challenging the System: Assumptions and Data Behind the Push for Single Sex Schooling," Gender in Policy and Practice: Perspectives on SingleSex and Coeducation Schooling, A. Datnow and L.Hubbard (eds.) Routledge Falmer.

Carrell, S.E, M.E. Page and J.E. West (2010), "Sex and Science: How Professor Gender Perpetuates the Gender Gap,” The Quarterly Journal of Economics, vol. 125(3), pp. 1101-44.

Close, S. and G. Shiel (2009), "Gender and PISA Mathematics: Irish results in context," European Educational Research Journal, vol. 8(1), pp. 20-33.

Cotton, C., F. McIntyre, and J. Price (2010), “The Gender Gap Cracks Under Pressure: A Detailed Look at Male and Female Performance Differences During Competitions,” NBER Working Paper 16436.

Currie, J. and R. Hyson (1999). "Is the Impact of Health Shocks Cushioned by Socioeconomic Status? The Case of Low Birthweight," American Economic Review, vol. 89(2), pp. 245-250. 
Dee, T. (2007), “Teachers and the Gender Gaps in Student Achievement," The Journal of Human Resources, vol. 42(3), pp. 528-554.

Department of Education and Skills (2007), “2020 Vision: Report of the Teaching and Learning in 2020 Review Group,"

Eisenkopf, G., Z. Hessami, U. Fischbacher and H. Ursprung (2012), “Academic Performance and Single-Sex Schooling: Evidence from a Natural Experiment in Switzerland,” University of Konstanz Working Paper.

Ellison, G and A. Swanson (2010), "The Gender Gap in Secondary School Mathematics at High Achievement Levels: Evidence from the American Mathematics Competitions," Journal of Economic Perspectives, vol. 24, pp. 109-128.

Else-Quest, N., J. Hyde and M. Linn (2010), "Cross- National Patterns of Gender Differences in Mathematics: A Meta-Analysis,” Psychological Bulletin, vol. 136(1), pp. 103-127.

Fryer, R., and S. Levitt (2010), “An Empirical Analysis of the Gender Gap in Mathematics” American Economic Journal: Applied Economics, vol. 2(2), pp. 210-240.

Gneezy, U., M. Niederle, and A. Rustichini (2003), "Performance in Competitive Environments: Gender Differences” The Quarterly Journal of Economics, vol. 118, pp. 1049-1074.

Gneezy, U. and A. Rustichini (2004), "Gender and Competition at a Young Age,” American Economic Review: Papers and Proceedings, vol. 114, pp. 377-381.

Gneezy, U., K. Leonard and J. List (2009), "Gender Differences in Competition: Evidence from a Matrilineal and a Patriarchal Society,” Econometrica, vol. 77(5), pp. 1637-1664.

Grogger, J. and E. Eide (1995), "Changes in College Skills and the Rise in the College Wage Premium,” The Journal of Human Resources, vol. 30, pp. 280-310.

Growing Up in Ireland (2010), The Lives of 9-Year-Olds. Research Report http://www.growingup.ie/fileadmin/user_upload/documents/1st_Report/Barcode_Growing_U p_in_Ireland_-_The_Lives_of_9-Year-Olds_Main_Report.pdf

Growing Up in Ireland (2010), Sample Design and Response in Wave 1 of the Nine-Year Cohort of Growing up in Ireland. http://www.ucd.ie/issda/static/documentation/esri/GUISampleDesign9YearCohort.pdf

Guiso, L., F. Monter, P. Sapienza and L. Zingales (2008), “Culture, Gender and Math,” Science, vol. 320(5880), pp. 1164-1165.

Halpern, D., C. Benbow, D. Geary, R. Gur, J. Hyde and M. Gernsbacher (2007), "The Science of Sex Differences in Science and Mathematics," Psychological Science in the Public Interest, vol. 8(1), pp. 1-51.

Halpern, D., L. Eliot, R. S. Bigler, R.A. Fabes, L.D. Hanish, J. Hyde, L.S. Liben, C. Lynn Martin (2011), “The Pseudoscience of Single-Sex Schooling," Science, vol. 333(6050), pp. 1706-1707. 
Hedges, L. and A. Nowell (1995), "Sex Differences in Mental Test Scores, Variability, and Numbers of High-Scoring Individuals,” Science, vol. 269(5220), pp. 41-45.

Hoxby, C. (2000), "Peer Effects in the Classroom: Learning from Gender and Race Variation,” NBER Working Paper 7867.

Huguet, P. and I. Régner (2007), "Stereotype Threat Among School Girls in Quasi-Ordinary Classroom Circumstances,” Journal of Educational Psychology, vol. 99, pp. 545-560.

Husain, M. and D. Milimet (2009), “The Mythical 'Boy Crisis'?,” Economics of Education Review, vol. 28, pp. 38-48.

Jackson, C. (2012), "Single-Sex Schools, Student Achievement and Course Selection: Evidence from Rule-Based Student Assignments in Trinidad and Tobago,” Journal of Behavior \& Organization, vol. 96, pp. 173-187.

Koedel, C. and E. Tyhurst (2012), "Math Skills and Labour Market Outcomes: Evidence from a Resume-Based Field Experiment,” Economics of Education Review, 31, pp. 131-140.

Lavy, V. and A. Schlosser (2011), "Mechanism and Impact of Gender Peer Effects at School,” American Economic Journal: Applied Economics, vol. 3, pp. 1-33.

Lee, V. and M. Lockheed (1990), "The Effect of Single-Sex Schooling on Achievement and Attitudes in Nigeria,” Comparative Education Review, vol. 34(2), pp. 209-231.

Lindberg, S., J. Hyde, M. Linn and J. Petersen (2010), "New Trends in Gender and Mathematics Performance: A Meta-Analysis” Psychological Bulletin, vol. 136(6), pp. 11231135.

LoGerfo, L., A. Nichols and D. Chaplin (2006), "Gender Gaps in Math and Reading Gains During Elementary and High School by Race and Ethnicity," Urban Institute http://www.urban.org/publications/411428.html

Mael, F.A., M. Smith, A. Alonso, K. Rogers and D. Gibson (2004), “Theoretical Arguments For and Against Single-Sex Schools: a Critical Analysis of the Explanations,” American Institutes for Research, Washington DC.

Mael, F.A., A. Alonso, D. Gibson, K. Rogers and M. Smith (2005), "Single-Sex Versus Coeducational Schooling: A Systematic Review," U.S. Department of Education, Office of Planning, Evaluation and Policy Department, Policy and Program Studies Service.

Machin, S. and S. McNally (2005), "Gender and Student Achievement in English Schools," Oxford Review of Economic Policy, vol. 21(3), pp. 357-372.

McCoy, S., E. Smyth and J. Burke (2012), "The Primary Classroom: Insights from the Growing Up in Ireland Survey,” Economic and Social Research Institute Working Paper.

Niederle, M., and L. Vesterlund (2007), "Do Women Shy Away from Competition? Do Men Compete Too Much?,” The Quarterly Journal of Economics, vol. 122(3), pp. 1067-1101.

Niederle, M. and L. Vesterlund (2010), "Explaining the Gender Gap in Math Test Scores: The Role of Competition,” Journal of Economic Perspectives, vol. 24(2), pp. 129-144. 
OECD (2007), Improving School Leadership OECD Project Background Report - Ireland, OECD: Paris.

OECD (2010a), http://www.oecd.org/dataoecd/11/28/44417824.pdf

OECD (2010b), PISA 2009 Results: What Students Know and Can Do, Student Performance in Reading Mathematics and Science, Volume 1, OECD: Paris.

Paglin, M. and Rufolo, A. (1990), "Heterogeneous Human Capital, Occupational Choice, and Male-Female Earnings Differences,” Journal of Labor Economics, vol. 8(1, Part 1), pp. 12344.

Park, H., J. Behrman and J. Choi (2011), “Causal Effects of Single-Sex Schools on Students' STEM Outcomes by Gender and Parental SES,” University of Pensylvania Working Paper.

Pekkarinen, T. (2012), “Gender Differences in Education,” IZA Discussion Paper 6390.

Riordan, C. (1985), "Public and Catholic Schooling: The Effects of Gender Context Policy," American Journal of Education, vol. 93, pp. 518-540.

Robertson Hayes, A., E. Pahlke, and R. Bigler (2011), "The Efficacy of Single-Sex Education: Testing for Selection and Peer Quality Effects," Sex Roles: A Journal of Research, vol. 65, pp. 693-703.

Robinson, J. and S. Lubienski (2011), “The Development of Gender Achievement Gaps in Mathematics and Reading During Elementary and Middle School: Examining Direct Cognitive Assessments and Teacher Ratings,” American Educational Research Journal, vol. 48(2), pp. 268-302.

Schrøter Joensen, J. and H. Skyt Nielsen (2010), "Is there a Causal Effect of High School Math on Labor Market Outcomes," The Journal of Human Resources, vol. 44(1), pp. 171198.

Schneeweis, N. and M. Zweimuller (2012), “Girls, Girls, Girls: Gender Composition and Female School Choice,” Economics of Education Review, vol. 31, pp. 482-500.

Smithers, A. and P. Robinson (2006), The Paradox of Single-Sex Schooling and CoEducational Schooling, Buckingham, United Kingdom: Carmichael Press.

Smyth, E. (2010), “Single-Sex Education: What does Research tell us?” Revue Française de Pédagogie, vol. 171, pp. 47-55.

Stecher, B. M. and S. P. Klein (1996), "Performance Assessments in Science: Hands-On Tasks and Scoring Guide,” Santa Monica, Calif.: RAND Corporation, MR-660-NSF.

Sullivan, A., H. Joshi and D. Leonard (2010), "Single-Sex Schooling and Academic Attainment at School and Throughout the Lifecourse," American Education Research Journal, vol. 47(1), pp. 6-36.

Sullivan, A., H. Joshi and D. Leonard (2011), "Single-Sex Schooling and Labour Market Outcomes,” Oxford Review of Education, vol. 37(3), pp. 311-332. 
Sugger, M. and D. Rutzler (2010), "Gender Differences in Competition Emerge Early in Life,” IZA Discussion Paper 5015.

Todd, P. and K. Wolpin (2003), "On the Specification and Estimation of the Production Function for Cognitive Achievement,” The Economic Journal, vol. 113(485), F3-33.

Todd, P. and K. Wolpin (2007), "The Production of Cognitive Achievement in Children: Home, School and Racial Test Score Gaps,” Journal of Human Capital, vol. 1(1), pp. 91-136.

Vollaard, B., L. Rabinovich, R. Bowman and C. van Stolk (2008), "Ten Years of Reform in Primary Mathematics Education in England: A Review of Effectiveness,” RAND Technical Report 632. 
Table 1. Drumcondra Test Reading and Maths Scores, GUI Sample

\begin{tabular}{|l|l|l|l|l|}
\hline & \multicolumn{2}{|c|}{ Reading } & \multicolumn{2}{c|}{ Maths } \\
\hline Percentiles & Males & Females & Males & Females \\
\hline $25^{\text {th }}$ & -0.707 & -0.608 & -1.387 & -1.372 \\
\hline $50^{\text {th }}$ & 0.067 & 0.051 & -0.678 & -0.769 \\
\hline 75 th & 0.765 & 0.742 & -0.012 & -0.223 \\
\hline & & & & -0.798 \\
\hline Mean & 0.007 & 0.046 & -0.695 & \\
\hline & & & & \\
\hline
\end{tabular}

Table 2. Probit Model of Maths Score: Probability of being in top quartile

\begin{tabular}{|l|l|l|l|}
\hline & $(1)$ & $(2)$ & $(3)$ \\
\hline Male & $.070^{* *}$ & $.055^{* *}$ & $.050^{* *}$ \\
& $(.014)$ & $(.014)$ & $(.014)$ \\
\hline All-Boys School & & $.041^{*}$ & $.044^{* *}$ \\
& & $(.025)$ & $(.022)$ \\
\hline All-Girls School & & -.010 & .009 \\
& & $(.024)$ & $(.024)$ \\
\hline Parental Education & & & $.108^{* *}$ \\
& & & $(.013)$ \\
\hline Family Income & & & $.001^{* *}$ \\
& & & $(.0002)$ \\
\hline Father Absent & & & $-.055^{* *}$ \\
& & & $(.018)$ \\
\hline DEIS School & & & $(.021)$ \\
\hline N & & & 7643 \\
\hline
\end{tabular}

Results reported are marginal effects. Sampling weights are used in estimating the model, and standard errors are adjusted for clustering at the school level.

** Significant at 5\% level, * significant at $10 \%$ level 
Table 3. Probit Model of Maths Score: Probability of being in top quartile, controlling for birthweight

\begin{tabular}{|l|l|l|}
\hline & $(1)$ & $(2)$ \\
\hline Male & $.054^{* *}$ & $.051^{* *}$ \\
& $(.014)$ & $(.014)$ \\
\hline All-Boys School & $.044^{* *}$ & $.043^{* *}$ \\
& $(.022)$ & .022 \\
\hline All-Girls School & .013 & .013 \\
& $(.024)$ & $(.024)$ \\
\hline Parental Education & $.108^{* *}$ & $.107^{* *}$ \\
& $(.013)$ & $(.013)$ \\
\hline Family Income & $.0008^{* *}$ & $.0008^{* *}$ \\
& $(.0002)$ & $(.0002)$ \\
\hline Father Absent & $-.055^{* *}$ & $-.053^{* *}$ \\
& $(.019)$ & $(.019)$ \\
\hline DEIS School & $-.08^{* *}$ & $-.08^{* *}$ \\
& $(.021)$ & $(.021)$ \\
\hline Child's Birthweight (Kg) & & $.023^{* *}$ \\
& & $(.010)$ \\
\hline & 7546 & 7546 \\
\hline
\end{tabular}

Sampling weights are used in estimating the model, and standard errors are adjusted for clustering at the school level.

** Significant at 5\% level, * significant at $10 \%$ level 
Table 4. Bivariate Probit Model of Maths Score in Top Quartile and School Choice ${ }^{\mathrm{a}}$

\begin{tabular}{|c|c|c|c|c|}
\hline & \multicolumn{2}{|c|}{ Boys } & \multicolumn{2}{|c|}{ Girls } \\
\hline & $\begin{array}{l}\text { School } \\
\text { Choice }\end{array}$ & Maths Score & $\begin{array}{l}\text { School } \\
\text { Choice }\end{array}$ & Maths Score \\
\hline Single-Sex School & & $\begin{array}{l}.679 * * \\
(.265)\end{array}$ & & $\begin{array}{l}.219 \\
(.258)\end{array}$ \\
\hline Parental Education & $\begin{array}{l}-.101 \\
(.076)\end{array}$ & $\begin{array}{l}.326 * * \\
(.057)\end{array}$ & $\begin{array}{l}-.055 \\
(.074)\end{array}$ & $\begin{array}{l}.389 * * \\
(.060)\end{array}$ \\
\hline Family Income & $\begin{array}{l}.001 \\
(.001)\end{array}$ & $\begin{array}{l}.003 * * \\
(.0009)\end{array}$ & $\begin{array}{l}-.00002 \\
(.001)\end{array}$ & $\begin{array}{l}.0015 * * \\
(.0007)\end{array}$ \\
\hline Father Absent & $\begin{array}{l}.013 \\
(.081)\end{array}$ & $\begin{array}{l}-.234 * * \\
(.084)\end{array}$ & $\begin{array}{l}.219 * * \\
(.083)\end{array}$ & $\begin{array}{l}-.156 * \\
(.091)\end{array}$ \\
\hline Urban & $\begin{array}{l}.647 * * \\
(.144)\end{array}$ & & $\begin{array}{l}.746^{* *} \\
(.129)\end{array}$ & \\
\hline DEIS School & $\begin{array}{l}.052 \\
(.199)\end{array}$ & $\begin{array}{l}-.288 * * \\
(.096)\end{array}$ & $\begin{array}{l}.275 \\
(.191)\end{array}$ & $\begin{array}{l}-.265^{* *} \\
(.097)\end{array}$ \\
\hline Constant & $\begin{array}{l}-.913 * * \\
(.126)\end{array}$ & $\begin{array}{l}-.927 * * \\
(.077)\end{array}$ & $\begin{array}{l}-1.007^{* *} \\
(.122)\end{array}$ & $\begin{array}{l}-.949 * * \\
(.080)\end{array}$ \\
\hline$\rho$ & & $\begin{array}{l}3 \% \\
65\end{array}$ & & \\
\hline $\mathrm{N}$ & 3700 & 3700 & 3943 & 3943 \\
\hline
\end{tabular}

a Since there are several marginal effects one could estimate following a bivariate probit we simply report the estimated coefficients for this model.

Sampling weights are used in estimating the model, and standard errors are adjusted for clustering at the school level.

** Significant at 5\% level, * significant at $10 \%$ level 
Table 5. Extended Probit Model of Maths Score: Probability of being in top quartile

\begin{tabular}{|l|l|l|}
\hline & $(1)$ & $(2)$ \\
\hline Male & $.050^{* *}$ & $.048^{* *}$ \\
& $(.015)$ & $(.014)$ \\
\hline All-Boys School & $.044^{*}$ & $.041^{*}$ \\
& $(.023)$ & $(.023)$ \\
\hline All-Girls School & -.007 & -.009 \\
& $(.024)$ & $(.025)$ \\
\hline Parental Education & $.109^{* *}$ & $.105^{* *}$ \\
& $(.013)$ & $(.013)$ \\
\hline Family Income & $.0009^{* *}$ & $.0009^{* *}$ \\
& $(.0002)$ & $(.0002)$ \\
\hline Father Absent & $-.044^{* *}$ & $-.055^{* *}$ \\
& $(.020)$ & $(.020)$ \\
\hline DEIS School & $-.083^{* *}$ & $-.08^{* *}$ \\
& $(.023)$ & $(.023)$ \\
\hline Teacher Male & & .012 \\
& & $(.021)$ \\
\hline Mother has Maths Occupation & & $.11^{* *}$ \\
& & $(.036)$ \\
\hline Division of Housework Unfair & & .009 \\
& & $(.013)$ \\
\hline Fixed-Gender Siblings & & -.006 \\
& & $(.013)$ \\
\hline & & $-.01^{*}$ \\
& & 6923 \\
\hline & & \\
\hline
\end{tabular}

Results reported are marginal effects. Sampling weights are used in estimating the model, and standard errors are adjusted for clustering at the school level.

** Significant at $5 \%$ level, * significant at $10 \%$ level 
Figure 1. Distribution of Maths and Reading Scores by Gender
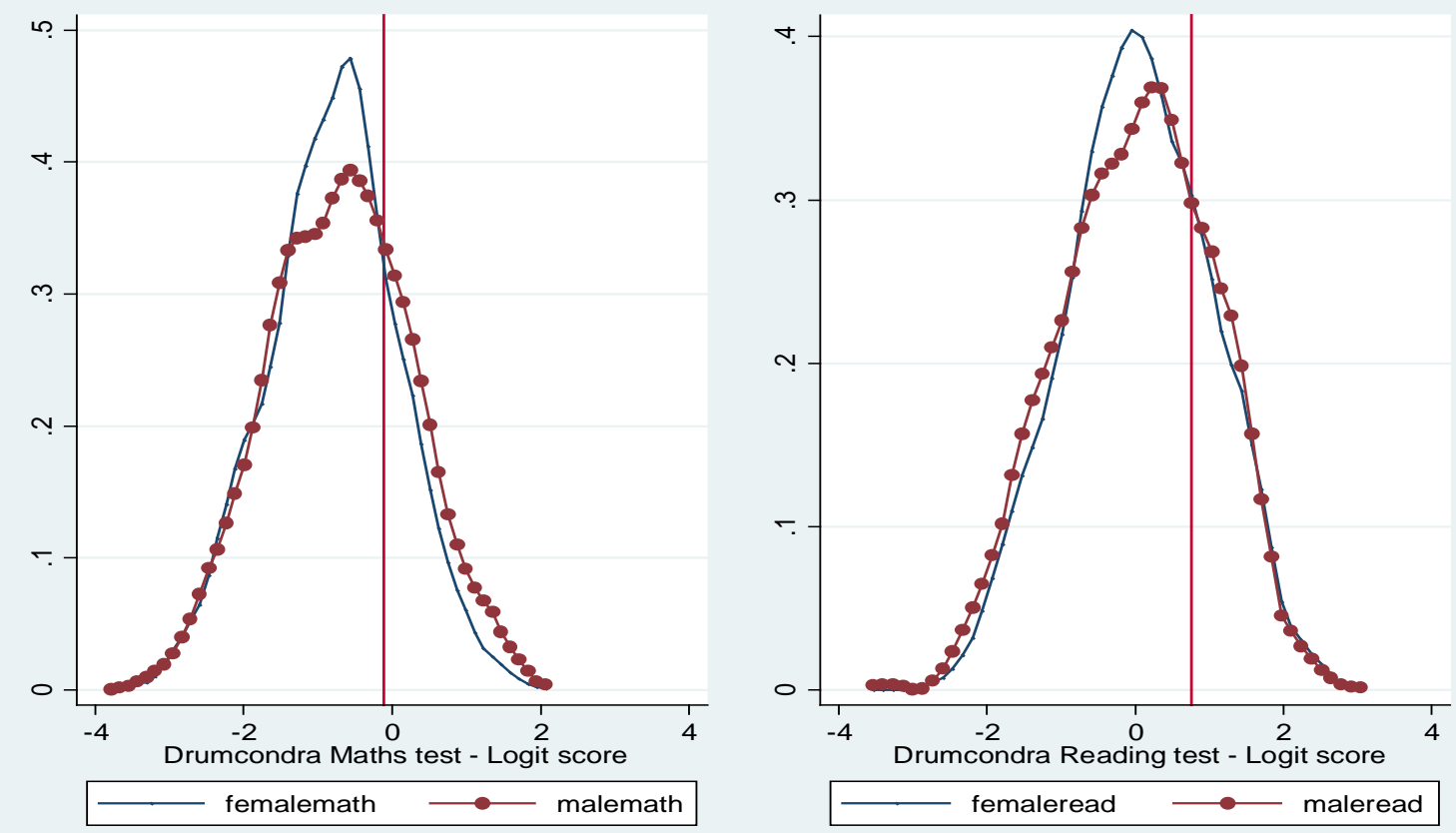
Figure 2. Distribution of Math Score by School Type and Sex of Child

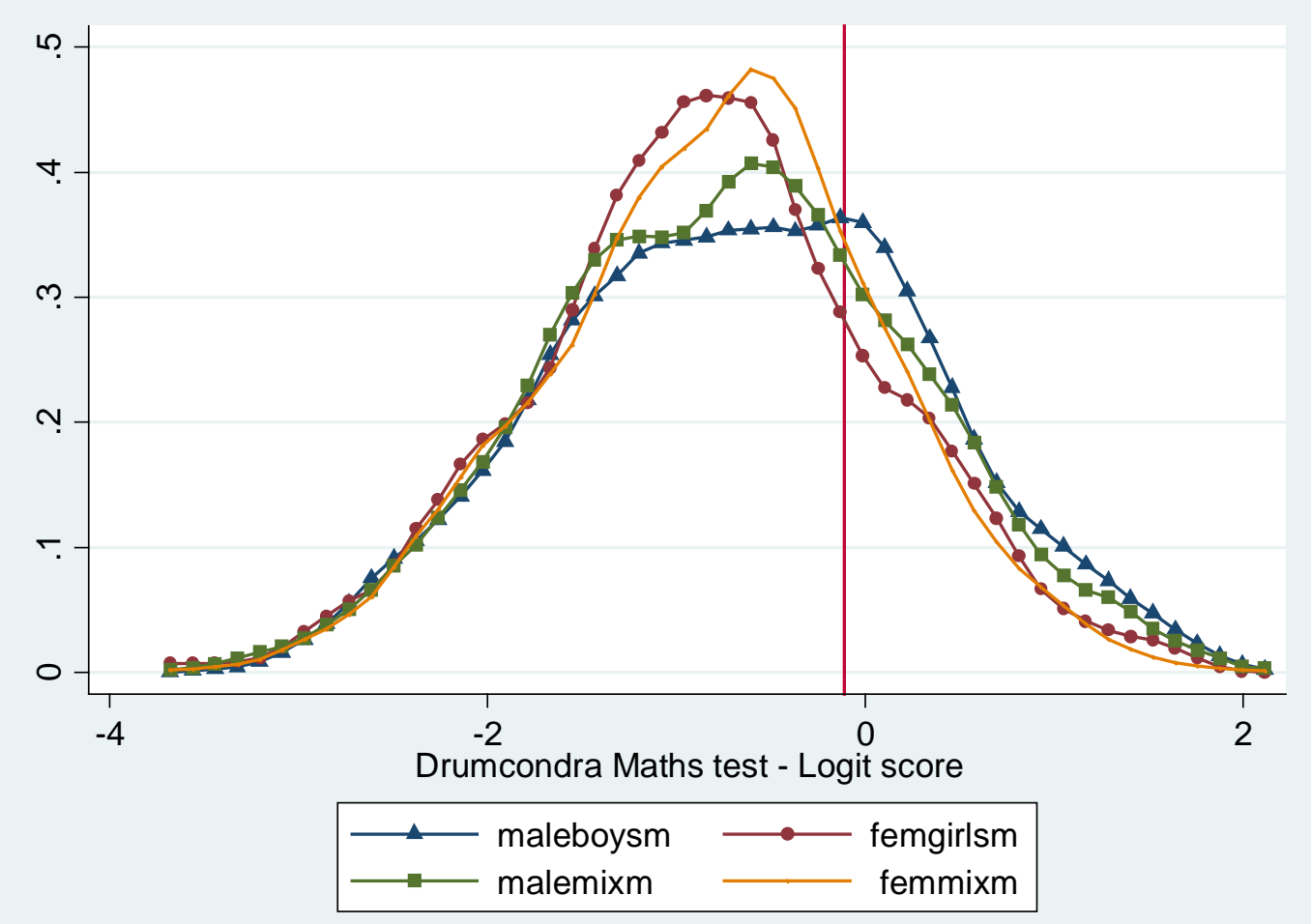


Appendix

Table A1. Summary Statistics

\begin{tabular}{|l|l|l|}
\hline & Boys & Girls \\
\hline Maths Score & -.56 & -.68 \\
\hline Single Sex School & .30 & .29 \\
\hline Parental Education: Degree & .39 & .35 \\
\hline Family Income (000’s) & 58.15 & 56.44 \\
\hline Father Absent & .13 & .15 \\
\hline Teacher Male & .18 & .11 \\
\hline Urban & .45 & .45 \\
\hline Mother with Maths Occupation & .03 & .024 \\
\hline Division of Housework Unfair & .36 & .37 \\
\hline Mixed-Gender Siblings & .63 & .64 \\
\hline Family Size & 2.78 & 2.78 \\
\hline DEIS School & .13 & .14 \\
\hline & & \\
N & 3345 & 3578 \\
\hline
\end{tabular}


Table A2. Probit Model of Reading Score: Probability of being in top quartile

\begin{tabular}{|l|l|l|l|}
\hline & $(1)$ & $(2)$ & $(3)$ \\
\hline Male & .009 & -.0003 & -.007 \\
& $(.013)$ & $(.014)$ & $(.014)$ \\
\hline All-Boys School & & .032 & $.036^{*}$ \\
& & $(.026)$ & $(.022)$ \\
\hline All-Girls School & & .0013 & .018 \\
& & $(.023)$ & $(.021)$ \\
\hline Parental Education & & & .151 \\
& & & $(.013)$ \\
\hline Family Income & & & $.0008 * *$ \\
& & & $(.0002)$ \\
\hline Father Absent & & & -.014 \\
& & & $(.019)$ \\
\hline DEIS School & & & $-.08^{* *}$ \\
& & $(.02)$ \\
\hline N & 7563 & 7563 & \\
\hline
\end{tabular}

Results reported are marginal effects. Sampling weights are used in estimating the model, and standard errors are adjusted for clustering at the school level.

** Significant at 5\% level, * significant at $10 \%$ level 